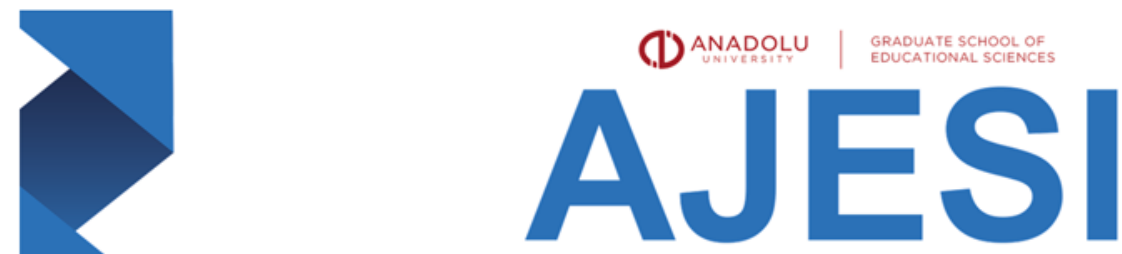

ANADOLU JOURNAL OF EDUCATIONAL SCIENCES INTERNATIONAL

DOI: 10.18039/ajesi.724391

Edebi Çeviri ve Çeviri Eleştirisi: Karşılaştırmalı Bir Çalışma

Behiye ARABACIOGLU ${ }^{1}$

Geliş Tarihi: 21.04 .2020

Kabul Tarihi: 04.06.2020

Makale Türü: Araştırma Makalesi

Öz

Çeviri eylemi tarihsel olarak bakıldığında Yunan-Roma Antik dönemine kadar uzanmaktadır. Somut olarak çevirilere ilk bu dönemde rastlanılmıştır. Daha sonraki dönemlerde de etkisini daima hissettirmiştir. Çeviri kadar çevirmenin ve çeviri eleştirisinin de önemi büyüktür. Zamanla nitelikli çeviri ve çevirmen ihtiyacı doğmuştur ve üniversitelerde Mütercim-Tercümanlık bölümleri açılmıştır. Amaç, piyasa çevirisi bakış açısını değil, akademik çeviri bakış açısını ortaya koymaktı. Derste yapılan çevirilerin ele alınmasının ve üzerinde tartışılmasının amacı, henüz bu işin başında olan genç kesim ile profesyonel çeviri yapanların aralarındaki farkı ortaya koyabilmektir. Nitel bir araştırma olan çalışmanın amacı durum çalışması olarak desenlenmiştir. Hedef dilde yazılmış bir eserden seçilen cümle ve paragrafların çevirisi derste öğrenciye yaptırılmıştır ve bu çeviriler veri olarak toplanmıştır. Verilerin analizi sürecinde içerik analizi yönteminden yararlanılmıştır. Öğrencilerin yaptıkları çeviriler birbiriyle karşılaştırılmıştır. Hataları ve seçimleri üzerinde durulmuştur. Farklılıkların nereden kaynaklanabileceği tartışılmıştır. Çalışmanın sonuç bölümünde çeviri ve çevirmenin önemine tekrar değinilerek, çeviri derslerinde öğrenciye nasıl daha fazla katkı sağlanabileceği tartı̧ılmıştır.

Anahtar kelimeler: çeviri, edebi çeviri, çeviri eleştirisi.

Atıf: Arabacıoğlu, B. (2020). Edebi çeviri ve çeviri eleştirisi: Karşılaş̧ırmalı bir çalışma. Anadolu Journal of Educational Sciences International, 10(2), 1004-1016. DOI: 10.18039/ajesi.724391

\footnotetext{
${ }^{1}$ (Sorumlu Yazar) Dr. Öğretim Üyesi, Anadolu Üniversitesi, Eğitim Fakültesi, Yabancı Diller Eğitimi Bölümü Alman Dili Eğitimi Anabilim Dalı, Türkiye, bceliker@anadolu.edu.tr, https://orcid.org/0000-0002-5868-5319
} 


\title{
Literary Translation and Translation Criticism: A Comparative Study
}

\author{
Behiye ARABACIOGLU ${ }^{1}$
}

\begin{abstract}
The act of translation dates back to the Greek-Roman Antique period. Concretely, translations were first encountered in this period. Its effect was always felt in later periods. Translation and translation criticism are as important as translation. Over time, the need for qualified translation and translators has arisen and Translation departments have been established in universities. The aim was to reveal the academic translation perspective, not the market translation perspective. The purpose of this is to reveal the difference between the young people who are at the beginning of this job and those who make professional translations. In this research, which was designed as a case study, the data were collected by translations of sentences and paragraphs selected from the work written in the target language. The data were analyzed using the content analysis method. The study includes sentence translations and paragraph translations performed by students taking literary translation lessons at the university. Translations made by students were compared with each other. Errors and choices were emphasized and where the differences might arise were discussed. In the conclusion part of the study, the importance of translation and translating is emphasized again, and suggestions to aid students in translation lessons are provided.
\end{abstract}

Keywords: translation, literary translation, translation criticism.

Cite: Arabacıoğlu, B. (2020). Literary translation and translation criticism. A comparative study. Anadolu Journal of Educational Sciences International, 10(2), 1004-1016. DOI: 10.18039/ajesi.724391

${ }^{1}$ (Corresponding Author) Asst. Prof. Dr., Anadolu University, Education Faculty, Department of Foreign Language Teaching, German Language Teaching Programme, Turkey, bceliker@anadolu.edu.tr, https://orcid.org/0000-0002-5868-5319. 


\section{Giriş}

"Edebi Çeviri" dersinde öğrencilere yaptırılan çeviriler birbirinden farklı sonuçlar ortaya koymuştur, çeviri çalışmalarının sonuçlarını karşılaştırmak ve bunun sonucunda çeviri dersinin öğrenci için nasıl daha etkili bir hale gelebileceği sorusunun cevabı bu çalışmanın amacını belirlemiştir. Peki, hangi çeviri kabul edilebilir çeviridir? Motamot dediğimiz sözcüğü sözcüğ̈ne tutan çeviri mi, yazarın duygularını yeterli olarak aktaran çeviri mi? Çeviri eylemi yıllar içinde kendisini geliştirmiştir. $\mathrm{Bu}$ nedenle soruların cevabı da günümüzde karşımıza daha farklı çıkacaktır. Çalışmanın ilk bölümünde geçmişten günümüze çeviri eleştirisi üzerinde durulup, sonrasında çeviri sorunlarına değinilecektir. Son bölümde farklı çeviriler üzerinde durularak, farklılıkların bilimsel olarak nedeni ortaya konmaya çalışılmıştır. Bu farklılıklara açıklamalar getirilerek üzerinde tartışılmıştır. Çeviriler, kaynak dilde yazılan ama Türk kültürünü anlatan E. Sevgi Özdamar'ın "Seltsame Sterne starren zur Erde" isimli romanından yapılmıştır. Kaynak dil ile anlatılan kültürün farklı olması derste öğrencilerle üzerinde çalışmak ve kültür aktarımını değerlendirebilmek açısından imkân sunmuştur. Fakat bu çalışmada sözü edilen kültürel aktarımın gerçekleşip gerçekleşmediği konusuna yer verilmemiştir.

\section{Kültür ve Çeviri Eleştirisine Tarihsel Bakış}

Kültürün tarihî ve sürekli olduğundan bahseden Güvenç (2003, s. 101), bir kuşaktan diğerine geçen kültürün her kültürde ortak neden ve sonuçlarının olduğuna ve böylece de süreklilik gösterdiğine değinir. Kültürün sürekliliğini sağlayan gelenekler ve göreneklerdir, dolayısıyla kültürün yaradılışa kadar uzanan bir geçmişi vardır. Bu kadar geçmişe uzanan kültür koşullar değiştikçe değişime uğrar, bu değişim uyum yoluyla gerçekleşir. Yani kültür yayılabilir, taşınabilir ve taşındığı yerde gerektiğinde şekil de değiştirebilir.

Çeviri yaparken kültürel ögelerin ana dilden hedef dile ya da hedef dilden anadile aktarılmasında kullanımsal ve deneyimsel eşdeğerlik açısından sorunlar ve zorluklarla karşılaşıldığını gözlemleyen Çoruk, Büyük ve Kayalı (2016, s. 118), toplumların davranış biçimlerinin ve kurallarının, geleneklerinin ve göreneklerinin, alışkanlıklarının birbirinden farklı olduğunu belirtmektedir. Bu, dillerinin birbirinden farklı olmasıyla ilişkilendirilmektedir. İşte dilin ve onun ürünü olan kültürde kendini hissettiren bu farklılık, toplumları değişik düşünme ve ifade etme biçimine götürür. Bu farklılıkları çevirirken birebir karşı1ıklar ya da eşanlamları aramaktan çok benzerlikleri ve çağrışımları yakalamak gerektiği savunulmaktadir.

Günümüzde çeviri etkinliği, tüm dünyada olduğu gibi ülkemizde de farklı amaçlarla gerçekleştirilmektedir. Ülsever' in $(2005$, s. 86) de dikkat çektiği nokta, öteki uluslarla iletişim kurmak, öteki kültürleri anlayabilmek için çevirinin vazgeçilmez bir edim haline geldiği gerçeğidir. Çeviriyi değerlendirme ölçütleri de gittikçe daha bilimsel hale gelmektedir. Üniversitelerde kurulan MütercimTercümanlık bölümleri, Çeviri bölümleri öncelikle nitelikli Çevirmen yetiştirmeyi hedeflemişlerdir. Çevirmen eğitiminin de üniversite düzeyinde ele alınması çeviri olgusuna daha nesnel ve bilimsel olarak yaklaşıldığının bir göstergesidir (Ülsever, 2005, s. 87). Edebi metinler, yazarın doğal dil birimlerini kendi düşüncesi doğrultusunda seçerek yarattı̆̆ olarak tanımlanabilirler. Çünkü yazar olağan dışı ve alışılmamış sözcük ve anlatımları kullanmıştır. Edebi çeviri ise bu noktada aynı görevi başka bir dilde yeniden kuran bir uğraş alanı olduğu için, aynı zamanda öteki olanı tanımada da vazgeçilmez bir araçtır (Ülsever, 2005, s. 108).

Çeviri eleştirisinin ilk dönemlerinde bir çeviri, kaynak metne ne kadar sadıksa ve kaynak metnin yazarının niyeti ne kadar yansıtılmışsa o kadar başarılı sayılırdı. Ancak, 20. yüzyılın ikinci yarısında 
çeviri Levy 1969, Reiss 1971, House 1977/1997, Holmes 1978, Koller 1979, Beaumgrande 1980, Gerzymisch-Arbogast 1994 gibi birçok model tarafından detaylı olarak sorunsallaştırılmıştır (Tosun, 2013, s. 166). Günümüzde, değerlendirme ölçütü artık daha çok Tosun'un da belirttiği gibi (2013, s. 166) çeviri eleştirisinin kaynak metinde değil de erek metin bağlamında aranması gerektiği yönündedir. Çünkü çeviri eleştirisi bu yönüyle, bitmiş bir ürün olarak, Çevirmenlerin yaptığı işleri değerlendirmek ve aynı şekilde çeviri yetisini geliştirecek ölçütler geliştirmek için neler yapılabileceği sorusunun cevabını aramak ister.

Öner'e göre (1993, s. 46) eleştiri tarihimize göz atıldığında, ülkemizde eleştirinin oluşumunda ve yaygınlaşmasında "Çeviri eleştirisinin" çok önemli bir yeri olduğu görülmektedir. Ve ülkemizde eleştirinin yıllar boyu sadece çeviri ile beslendiği görüşünün de oldukça yaygın olduğu açıtır. Öner ayrıca, eleştirel bilincin gelişmesi için, çeviri kuramlarının ayrıntılı olarak incelenmesi, sorgulanması, çeviri eleştirisine yansıyacak yönlerinin belirlenmesi ve gerektiğinde yeni varsayımların üretilmesi, yani kuramların oluşturulması gerektiğini savunur. Böylece eleştirmenler eleştirilerinin özünü "çelişkili" kuralcı kuramların oluşturduğu paradigmanın çizgisinde yapmaktan kurtulabilirler.

Çağdaş çeviri kuramlarında ve çalışmalarında benimsendiği şekliyle, Yıldız'ın da (2004, s. 385) belirttiği gibi çeviri eleştirisi, genel çeviri kuramı, çeviri edimi ve çeviri amaçlı tüm uğraşlar çerçevesinde çok verimli, gerekli ve önemli bir çalışma alanıdır. Özellikle yirminci yüzyılın ortalarına kadar eleştiride 'hata avcılığının' ötesine geçilememiştir ve sınırlı bir yaklaşım sunulmuştur. Bunun nedeni, çeviri kuramcıları tarafından ileri sürülen farklı çeviri eleştiri modellerinin genellikle salt kaynak metnin dilsel göstergelerine odaklanmasıydı. Ancak zamanla çeviri kuramlarında olduğu gibi çeviri eleştirisinde de erek metnin ön plana çıkmasıyla, metinlerin işlevsel nitelikleri önem kazanmaya başlamıştır (Yücel, 2007, s. 54). Yapılan bu tespitler Çeviri eleştirisinin gerekli ve önemli bir çalışma alanı olmasının yanı sıra karmaşık bir olgu olduğunu da göstermektedir.

\section{Çeviri Sorunları ve İlgili Kuramlar}

Çeviri eylemi tarihsel olarak bakıldığında Yunan-Roma Antik dönemine kadar uzanmaktadır. Somut olarak çevirilere ilk bu dönemde rastlanılmıştır. Daha sonraki dönemlerde de etkisini daima hissettirmiştir (Stolze, 2013, s. 22). Duygu ve düşüncelerin kurgulanması sonucu ortaya muhteşem edebi eserler çıkabilmektedir. Edebi eser dendiğinde, Roman, öykü, şiir gibi tüm kurmaca metinler akla gelmelidir. İşin içinde duygu ve düşünceler olduğundan, bunlara tercüman olmak hayli zor bir iştir. Çeviri yaparken edebi bir eser söz konusu ise, aynı duyguyu ve hazzı aktarabilmek en iyi çevirmenleri dahi zorlayabilir. Çeviri yapan kişi, kendisini bir düşünme çabası içinde bulur, çevireceği metnin cümlelerini ortaya çıkararak, bu cümlelerdeki kelimelerin anlamlarına eğilir, bu anlamları saptayıp kavradığından emin olduktan sonra da çeviri işlemini uygulamaya başlar (Baykan, 2005, s. 180). Bu nedenle edebi eser çevirisini, diğer çeviri işlerinden farklı değerlendirerek edebi çeviri yapmanın daha karmaşık bir süreçte gerçekleştiğini kabul etmek gerekir.

Moran (2001, s. 115), sanatın sanatçının duygularını dile getirmesiyle değil, aksine bu duyguların okura da duyurulması, aynı heyecanların, yaşantıların onda da uyandırılması ile meydana geldiğini savunur. Buradan yola çıkarak aktarımcılar sanatçının dile çevirdiği duyguyu okura da duyurabilmesini sanatın koşulu olarak ortaya sürerler. Çevirmen de bir aktarımcı olarak aynı sorumluluklara sahiptir. Sanatçının duygusunu okuyucuya aktarabilmek, üstelik farklı bir dil ve kültürde olağanüstü bir beceri ister. Kültürel sorunlar sanatsal dil kullanımını aktarma sorunları gibi çevirmeni en çok zorlayan sorunlardandır. Çünkü kaynak metinde yer alan herhangi bir kültürel kavram erek dilde ve kültürde yer almıyorsa, bu durum çevirmen için sorun oluşturmaktadır (Ülsever, 2005, s. 115). 
Çeviri bilimi ancak 70'li yılların başında başlamıştır. İlk dönemlerinde çeviri, metne sadık olmasıyla ya da kelimesi kelimesine çeviri olarak yapılması açısından incelenirdi. Bir çeviri kaynak metne ne kadar sadıksa ve kaynak metnin yazarının niyetini ne kadar yansıtırsa o kadar başarılıydı (Tosun, 2013, s. 165).

Alımlama estetiği kuramının temsilcilerinden biri olan Wolfgang İser de bu kuramın anlayışına göre, edebi metnin anlamının metin içinde hemen hazır beklemediğini ve bazı ipuçları verilerek, okuyucu tarafından yavaş yavaş bağlantı kurulması istendiğini savunur. Anlam, ancak okur tarafından alımlandığı sürece somutlaşır ve bütünleşir (Moran, 2001, s. 241). Çeviri sorunları üzerine alanda birçok çalışma yapılmıştır ve yapılmaya devam edeceği şüphesizdir. Bu çalışmanın genel amacı üniversitede okuyan öğrencilere bilimsel anlamda çeviri dersinde çeviri ve çeviri eleştirisi alanındaki beceri ve başarılarını ortaya koymaktır ve nasıl daha fazla katkı sağlanabileceği konusunda bilgi toplamak ve bunları sunmaya çalışmaktır.

\section{Yöntem}

Çalışma, nitel araştırma yöntemlerinden durum çalışması olarak desenlenmiştir. Nitel araştırmalarda veriler yaygın olarak üç tür yöntem ile toplanır; görüşme, gözlem ve yazılı materyallerin incelenmesi. Nitel araştırmalarda sayısal verilere ve istatistiklere daha az yer verilirken, sözlü ve nitel analizlere daha çok vurgu yapılır. Nitel araştırmacılar olayların ve bağlamların dilini kullanır, olayları bağlamı içerisinde inceler (Karataş, 2015, s. 64). Bu çalışmada Eskişehir Osmangazi Üniversitesi FenEdebiyat Fakültesi, Karşılaştırmalı Edebiyat Bölümü’nde 2015-2016 öğretim yılının Güz döneminde yürütülen Almanca Edebi Çeviri I dersini alan öğrencilerin derste yaptıkları çeviriler incelenmiştir ve içerik analizi temel amaçları doğrultusunda yorumlanmıştır.

\section{Araştırma Grubu}

Edebi çeviri dersinin çıkış noktası öğrencilere eleştirel bakış açısını kazandırabilmektir. Bu amaçla aşağıda adı geçecek olan Fakülte ve bölümde zorunlu ve VII. ile VIII. dönemde okutulan bir ders olan Almanca Edebi Çeviri I dersi için Almanca yazan bir Türk yazarının romanı tercih edilmiştir ve güz dönemi boyunca üzerinde çalışılmıştır.

Çalışmaya katkı sağlayan öğrencilerden iki tanesinin sonuçları karşılaştırılıp yorumlanmıştır, bu öğrenciler sonuç bölümünde Öğrenci 1 ve Öğrenci 2 diye adlandırılmıştır. Her iki öğrenci de Eskişehir Osmangazi Üniversitesi Fen Edebiyat Fakültesi, Karşılaştırmalı Edebiyat Bölümü’nden seçilmiştir. Bölümün hazırlık sınıfını Almanca okuyarak A1-A2 dil seviyesine ulaşan öğrenciler eserden kesitleri zorlanmadan okuyabilmişlerdir.

\section{Veri Toplama}

Çalışmada elde edilen veriler içerik analizi yöntemi ile incelenmiştir. Araştırma kapsamında öğrencilerin derste yaptıkları çeviriler incelenmiştir, konuyla ilgili olgu ve olaylar hakkında bilgi içeren yazılı belgeler analiz edilmiştir, dolayısıyla veri sağlanması doküman incelemesi ile gerçekleştirilmiştir. Araştırma yapılan alanla ilgili pek çok bilgi Karataş'ın da belirttiği şekilde, görüşme ve gözlem yapmaya gerek kalmaksızın belge inceleme yoluyla elde edilebilir (2015, s. 72). 
Metin seçimi yapılırken göçmen edebiyatından bir roman tercih edilmesinin başlıca nedeni yazarın Türk oluşu, romanda Türkçe unsurların bulunması ve eser dilinin öğrencilerin de zorlanmadan anlayabilecekleri şekilde sade ve akıcı olmasıdır.

Dersin başında göçmen edebiyatı hakkında genel bir bilgi verildikten sonra yazarın hayatı ile ilgili bilgiler de verilmiştir. Kitabın yazıldığı dönem Almanya tarihi açısından önemli bir dönem olduğundan dolayı 70'li yılların Berlin'i hakkında da kısa bir bilgi aktarılmıştır. Roman kesitler halinde incelenip üzerinde çeviri çalışmaları yapılmıştır. Ayrıca romanın Fikret Doğan tarafından çevrilmiş ve basılmış olan hali ile de karşılaştırmalı çalışmalar yapılmıştır. Romandan seçilen kesitler yerine göre cümle ve paragraflardan oluşmaktadır. Romanın yazarı Türk olduğundan, eseri Türk kültüründen öğelerle bezelidir. Almanya'da yaşadığı için ve romanı Almanca yazdığı için de okura kültürlerin iç içe geçtiği zengin bir dünya sunulmuştur. Çalışmada, öğrencilerle derste yapılan ve farklılıklar gösteren çevirilere yer verilerek sonuçlar yorumlanacaktır. Öncelikle cümle bazında yapılan çeviriler üzerinde durulacak devamında ise paragraf çalışmalarına göz atılacaktır. Öğrencilerin yanı sıra, çevirmenin de çevirilerine yer verilecektir.

\section{İnceleme ve Bulguların Yorumlanması}

Çalışmanın inceleme bölümünde kaynak metinden seçilen kesitlerin yapılan çevirileri karşılaştırılmıştır ve çeviri eleştirisi bağlamında yorumlanarak bir çalışma modeli benimsenmiştir. Karataş'ın da belirttiği üzere, içerik analizi ile temelde yapılan işlem, birbirine benzeyen verileri belirli kavramlar ve temalar çerçevesinde bir araya getirmek ve bunları okuyucunun anlayabileceği bir biçimde düzenleyerek yorumlamaktır (2015, s. 74). Seçilen örneklerde üç farklı çeviri üzerinde durulmuştur. Eleştiri açısından önemli olabilecek bölümler ise, dilsel düzeyde bir karşılaştırma yapılarak incelenmiştir.

Çeviri, anlamı aynı olan yeni bir metin oluşturur (Metzler, 2007, s. 789). Bu doğrultuda aynı anlamı içeren, aynı mesajları ileten fakat birbirinden farklı kurgulanmış örnek cümle çevirileri aşağıda verilmiştir. Öğrenci çevirilerinde yerine göre daha çok anlam kayması ve yanlış sözcük kullanımına rastlamak mümkün, ancak bu durumun da öğrencilerin dil seviyeleri ve birikimleri göz önünde bulundurulursa normal olarak değerlendirilmesi gerektiği kaçınılmaz bir gerçektir.

Çalışmanın bundan sonraki aşamasında öğrencilerle derste çevirisi yapılan, üzerinde çalışılan birçok cümle ve paragraftan bazıları seçilerek verilmiştir. Öncelikle öğrencilerden seçilen çeviriler, sonra "Seltsame Sterne starren zur Erde" eserini Türkçe'ye çeviren Fikret Doğan'ın çevirisine yer verilmiştir.

Cümle 1: "Ich fuhr jetzt jeden Tag hinüber. Ich kannte jeden Grenzbeamten, und wenn einer nieste, sagte ich 'Gesundheit'...” (Özdamar, 2003, s. 42)

\section{Cümle 1 için yapılan çeviriler:}

(Öğrenci 1) "Şuanda olduğu gibi her gün öbür tarafa giderim, her sınır memurunu tanırım ve birisi hapşurduğu zaman 'sağllklı yaşa' derim."

(Öğrenci 2) "Her gün diğer tarafa geçiyordum, her bir gümrük memurunu tanıyordum ve ne zaman içlerinden biri hapşırsa 'çok yaşa' diyordum." 
(Doğan, 2012, s. 35) "Her gün öbür tarafa geçiyordum. Tanımadı̆̆ım sınır memuru yoktu, biri hapşırdı mı 'çok yaşa,' diyordum."

Öğrenci 1'in yaptığ cümle çevirisi içerik ve anlam olarak çok yanlış değil, fakat gramer olarak hatalıdır. Eser orijinalde (Präteritum) geçmiş zamanda anlatılmış, öğrenci 1 ise geniş zamanı kullanmıştır. "jetzt” sözcüğü artık anlamında kullanılmıştır ancak öğrenci 1 şimdi anlamında çevirmiştir. Ayrıca doğrusu hapşırmak olan niesen fiilini hapşurmak olarak kullanmıştır. Burada Türkçe kullanım hatası da söz konusudur.

Öğrenci 2 jetzt sözcüğünü kullanmadan her gün diğer tarafa geçildiğini ifade etmiş olmakla birlikte artık demediği için bir rutine dönüştüğünü belirtmek isteyen yazarın ifadesini eksik bıraktığı düşünülebilir.

Doğan'ın çevirisinde anlam kaybı yoktur, çevirmenin tercihi doğrultusunda cümle yapıları farklı olmuştur. Bu durumda da çevirmenin özgürlüğü devreye girmektedir.

Cümle 2: "Als ich gerade die vierte Seite umblätterte, trat ein Mann in das halbdunkle, kleine Archivzimmer." (Özdamar, 2003, s. 39)

\section{Cümle 2 için yapılan çeviriler:}

(Öğrenci 1) "Ben henüz dört sayfa çevirirken, küçük loş arşiv odasında bir adama tekme atıyordu."

(Öğrenci 2) "Ben tam dördüncü sayfayı çevirdiğimde, bir adam loş, küçük arşiv odasına daldı."

(Doğan, 2012, s. 32) "Tam dördüncü sayfayı çeviriyordum ki loş arşiv odasına bir adam girdi."

Öğrenci 1'in yapmış olduğu cümle çevirisi tamamen hatalıdır. Anlam olarak da gramer olarak da yanlıştır. "Trat" fiili “treten" fiilinin Präteritum (geçmiş zaman) çekimidir. Ortaya çıkmak (auftreten), içeri girmek (eintreten), incitmek (verwunden), ayak basmak (betreten), gelmek (treten) gibi farklı kullanımları vardır, Öğrenci sözlükte ilk olarak tekme diye bulmuştur ve kullanmıştır.

Öğrenci 2'nin çevirisi doğrudur. Küçük farklılıklar yine çevirmenin yapacağı tercihler doğrultusunda görünmektedir.

Çevirirken ile çeviriyordum $k i$ arasında herhangi bir anlam farkı yok gibi görünse de çeviriyordum ki'nin altında çevirmeden içeriye bir adam girdi anlamı yatar. Dolayısıyla sayfa çevirme işi bitmemiş olacak şeklindeki ifadeyi doğru kabul etmeli.

Cümle 3: "Am Alexanderplatz gab es ein Restaurant, den Alextreff, wo das Essen sehr billig war, so dass mir von den sechs Mark fünfzig noch genug Geld übrigblieb, um abends ins Theater zu gehen." (Özdamar, 2003, s. 43)

\section{Cümle 3 için yapılan çeviriler:}

(Öğrenci 1) “Alexanderplatz'da Alextreff adında yemekleri çok ucuz olan bir restoran vardl. O kadar ucuzdu ki bana akşamları tiyatroya gitmek için 6 marktan geriye yeterince para artıyordu."

(Öğrenci 2) 'Alexander meydanında 'Alextreff' adında bir restoran vardı, orada yemekler çok ucuzdu, hatta akşamları tiyatroya gitmek için 6.15 mark para üstüm bile kalırdı."

(Doğan, 2012, s. 35) "Alexanderplatz'da Alextreff adında bir lokanta vardl, yemekleri sudan ucuzdu, o kadar ki, akşamları tiyatroya gitmek için altı buçuk marktan yeterince para kalıyordu bana." 
Öğrenci 1'in çevirisi 6.5 mark demiş olsaydı tamamen doğru kabul edilebilecek düzeydedir. Öğrenci 2'de cümlenin ikinci kısmında eksik vardır. 6,5 marktan artan para ile tiyatroya gidebileceği anlaşılmamış. Doğan'ın çevirisinde sudan ucuzdu ifadesi fazladan olmuştur. Fakat bu şekilde kullanmak tercihe bağlıdır.

Çalışmanın devamında ise yukarıda adı geçen öğrenci grubuyla dönem içerisinde üzerinde durulmuş paragraf çevirilerinden iki tanesi seçilmiştir.

\section{Paragraf 1:}

"Jetzt holte sie Josef auch für mich. 'Doktor, komm, hilf ihr.' Josef setzte sich auf einen Stuhl neben meinem Bett. 'Warum weinst du?' 'Ich bin unglücklich in meiner Sprache. Wir sagen seit Jahren nur solche Sätze wie: Sie werden sie aufhängen. Wo waren die Köpfe? Man weiß nicht, wo ihr Grab ist. Die Polizei hat die Leiche nicht freigegeben! Die Wörter sind krank. Meine Wörter brauchen ein Sanatorium, wie kranke Muscheln. Es gibt eine Stelle am Ägäischen Meer, wo drei Ströme zusammenkommen. Man bringt Säcke mit Muscheln aus Istanbul, Izmir, Italien dorthin, die im schmutzigen Wasser krank geworden sind. Das saubere Wasser aus den drei Strömen heilt in ein paar Monaten die erkrankten Muscheln. Dieses Stück Meer nennen die Fischer Muschelsanatorium. Wie lange braucht ein Wort, um wieder gesund zu werden? Man sagt in fremden Ländern verliert man die Muttersprache. Kann man nicht auch in seinem eigenen Land die Muttersprache verlieren? ' "(Özdamar, 2003, s. 23)

\section{Paragraf 1 için yapılan çeviriler:}

(Öğrenci 1) Şimdi benim için de Josef'i çağırdl. "Doktor, gel ona yardım et." Josef yatağımın yanı başında duran bir sandalyeye oturdu. "Neden ağllyorsun?" "Kendi dilimden mutsuzum. Yıllardan beridir sadece: Onlar onları asacaklar. Kafalar nerede? Onun mezarının nerede olduğunu kimse bilmiyor? Polis cesedi serbest bırakmadı! Cümlelerini kuruyoruz. Kelimeler hasta. Kelimelerimin tıpkı deniz kabuklarının ki gibi bir sanatoryuma ihtiyacı var. Ege denizinde üç akıntının birleştiği bir nokta var. Insanlar İstanbul'dan, İzmir'den, Italya 'dan kirli denizlerinden dolayı hastalanan çuval çuval deniz kabuklarını oraya getiriyor. Üç akıntının birleşmesiyle oluşan bu temiz su deniz kabuklarını birkaç ayda iyileştiriyor. Balıkçılar denizin bu kısmına deniz kabuğu sanatoryumu diyor. Peki, bir kelimenin tekrar sağllğına kavuşması için ne kadar süreye ihtiyacı var? Derler ki, yabancı bir toprakta insan kendi ana dilini unutur. İnsan kendi topră̆ında da ana dilini unutamaz mı?”

(Öğrenci 2) Josef yată̆ımın yanında oturuyor. "Neden ă̆llyorsun?” Dilimden memnun değilim. Yıllardır aynı cümleleri kuruyoruz. Mesela, örneğin; onlar onu alacak. Kelleler nerede? Onun mezarının nerede olduğu bilinmiyor. Polisler cesetleri bırakmıyor. Kelimeler hasta. Benim kelimelerim hasta bir midye gibi tedaviye ihtiyacı var. Ü̧̧ nehrin birlikte akttğ bir yer var. İnsanlar şifalı su midyelerini iyileştirsin diye İstanbul'dan, İzmir'den ve Italya'dan geliyorlar. Üç yerden birden akan şifalı ve temiz su birkaç ayda midyeleri iyileştirebilir. Balıkların olduğu bu parçaya midye sanatoryumu denmektedir. Bir kelimenin sağlıklı olması ne kadar sürer? Adam anadilin yabancı yerlerde kaybettiğini söyledi. Anadil kendi ülkesinde de özünü kaybedemez mi?

(Doğan, 2012, s. 19) 'Şimdi Josef'i benim için de çağırıyordu. ,Doktor, gel yardım et ona '. Josef yatağımın yanındaki bir iskemleye oturdu. ,Neden ağllyorsun?' ,Kendi dilimde mutsuzum. Yıllardır ă̆zımızdan sadece şöyle cümleler çıkıyor: Onları asacaklar! Cesetleri dört bir yana dă̆ılmış! Mezarlarının nerede olduğu bilinmiyor? Polis cesede el koydu, kimseye göstermiyor! Kelimeler hasta. Kelimelerimin bir sanatoryuma yatması lazım, aynı hasta midyeler gibi. Ege denizinde üç akıntının birleştiği bir yer var. Kirli suda hastalanmış midyeleri İstanbul'dan, İzmir'den, İtalya'dan çuval çuval 
oraya getirirler. Üç akıntının temiz suyu bir kaç ay içinde hasta midyeleri iyileştirir. Balıkçılar bu deniz parçasına midye sanatoryumu derler. Bir kelimenin yeniden şifa bulması ne kadar sürer? Yabancı ülkelerde insan anadilini yitirir derler. Insan kendi ülkesinde de anadilini yitiremez mi?"”

"Jetzt" şimdi demektir fakat burada kattı̆g 1 anlam artık, nihayet anlamındadır. Josef zaten eve çağırılan biriydi, artık benim için de çağırılıyordu denmek istenmiş burada. Öğrenci çevirilerinde ve Çevirmenin çevirisinde şimdi kullanılmıştır. Metnin orijinalinde "Stuhl” sözcüğü yerine sandalye denmesi daha uygundur. İskemle arkalığı olmayan tabure tarzı bir mobilyadır. Ve iskemle ya da taburenin Almancası Hocker'dır. Her iki öğrenci de "dilimden mutsuzum” ifadesini kullanmıştır. "Dilimde mutsuzum" daha doğru olacaktır. "Onun mezarının nerede olduğunu bilmiyorlar" cümlesinde "ihr” çoğuldur, fakat her iki öğrenci de "onun” anlamında kullanarak yanlış yapmıştır. Öğrenci 2 "mesela, örneğin” demiştir, bu kullanım Türkçede yanlıştır. Öğrenci 1'in çevirisi öğrenci 2'nin çevirisine kıyasla daha doğru bir çeviridir. "Man sagt, ..." diye başlayan cümlenin "adam diyor ki", ya da "adam dedi” olarak çevrilmesi hatalıdır, kabul edilemez. Doğan'ın çevirisi uygun bir çeviri olarak değerlendirilebilir.

\section{Paragraf 2:}

“10. Juni 1976. Früh am Morgen fuhren wir wieder zu dem See und legten unsere Decke an denselben Platz. Die Sonne brannte, neben uns saßen eine Mutter und ihre Tochter, vor mir las ein Junge Dantons Tod von Büchner. Auf der Wiese schliefen nackte Männer wie friedliche Tiere im Wald. Drei Homosexuelle streichelten sich, auch der Faschist von gestern war wieder da, später schwamm er mit einer Frau im See. Im Lautsprecher sagte die Stimme eines Volkspolizisten: 'Seien Sie verantwortungsbewusst gegen Waldbrand' mein hintern und meine Brüste haben noch nie so viel Sonne abbekommen und waren sofort verbrannt. Gleichheit und Freiheit für alle Körperteile! Als wir in die Stadt zurückkehrten, habe ich vergessen meine Unterhose anzuziehen.” (Özdamar, 2003, s. 138)

\section{Paragraf 2 için yapılan çeviriler:}

(Öğrenci 1) 10 Haziran 1976. Sabah erken, tekrar göle gittik ve örtümüzü ayn yere koyduk. Güneş yakıyordu, yanımızda bir anne ve onun kızı oturuyordu, önümde bir genç Büchner'in "Dantons'un Ölümü” kitabını okuyordu. Çimenliğin üzerinde ormandaki rahat hayvanlar gibi çıplak adamlar uyuyordu. Üç homoseksüel birbirlerini okşuyorlardl. Dünkü faşist de yine ordaydı ve daha sonra bir bayanla gölde yüzdü. Hoporlörde bir halk polisinin sesi; "orman yangınına karşı tedbirli olunuz” diyordu. Popom ve gögü̈slerim hiç de fazla güneş almamışlardı ve hemen yanmışlardl. Tüm vücut parçalart için eşitlik ve özgürlük! Biz şehre geri dönerken donumu giymeyi unuttum.

(Öğrenci 2) 10 Haziran 1976. Sabah erkenden yine denize gittik ve örtümüzü aynı yere koyduk. Yanımızda bir anne ve genç Danton'un öldüğü kitabı okuyan kızı oturuyordu. Çayırda ormandaki sakin hayvanlar gibi çıplak adamlar uyuyordu. Ü̧̧ homoseksüel birbirini okşuyordu. Dünkü faşist de yine ordaydı daha sonra bir kadınla denizde yüzdü. Hoparlörde bir polis sesi "Orman yangınına karşı bilinçli olun." Kalçam ve göğüslerim yeteri kadar güneşten nasibini almadl ve hemen yandılar. Eşitlik ve özgürlük tüm organlar için! Şehre döndüğ̈̈müzde külotumu giymeyi unuttum.

(Doğan, 2012, s. 118) "10 Haziran 1976. Sabah erkenden gene göle gittik, havlularımızı gene aynı yere serdik. Güneş yakıcıyd, yanımda bir anneyle kızı oturuyordu, karşımda bir genç kitap okuyordu. Büchner'in Danton'un Ölümü. Çayırda çıplak erkekler uyuyorlardl, ormandaki barışçıl hayvanlar gibi. Üç eşcinsel birbirlerini okşuyorlardl, dünkü faşist de gene buradaydl, daha sonra bir kadınla beraber gölde yüzdü. Hoparlörden bir halk polisinin sesi duyuldu: 'Orman yangıılarına karşı sorumluluğunuzun bilincinde olun. 'Kıçım ve göğüslerim hiç bu kadar güneş yüzü görmemişti, anında 
yandılar. Vücudun bütün organları için eşitlik ve özgürlük! Şehre geri döndügümüzde külodumu giymeyi unuttum."

Öğrenci 1'in çevirisi oldukça başarılı. Bayan yerine kadın kullanımını tercih etmeliydi. "Daha önce hiç bu kadar" anlamı olan "Noch nie so viel" kalıbını "hiç de fazla güneş almamışlardı" şeklinde çevirerek hata yapmıştır. Son cümlede "Biz" denmese de olur. Öğrenci 2 çeviriye güzel başlamış ancak ikinci cümlede hata yapmıştır. Cümle tamamen yanlış, çünkü anlamı da farklı olmuş. Yanımızda bir anne ve genç Danton'un öldüğü kitabı okuyan kızı oturuyordu. Anne ve kız oturuyor, Danton'un kitabını okuyan ise bir genç. "Kalçam ve göğüslerim yeteri kadar güneşten nasibini almadı ve hemen yandılar" cümlesi de hatalı çevrilmiştir, çünkü daha önce hiç bu kadar yanmamıştı ifadesinin karşılığını vermemektedir. Doğan'ın çevirisi uygun bir çeviri olmuştur. En son cümlede külodumu giymeyi unutmuşum diye çevirmeyi tercih edebilirdi. Yazarın, bunun yanlışlıkla olduğunu, tamamen dalgınlığına geldiğini, günün yorgunluğuna bağladığını vurgulamak istediği düşünülebilir.

\section{Tartışma, Sonuçlar ve Öneriler}

Çalışmanın başında belirtildiği gibi, kullanılan öğrenci çevirileri daha önce derste üzerinde çalışılan romandan kesitlerdir. Çeviriler üzerinde ayrıntılı bir şekilde durulmuştur, yapılan her bir cümle için öğrencilere dönüt verilmiştir. Dolayısıyla öğrenci çevirisi ve kitabın çevirmenine ait çeviriler derste öğrenci ile birlikte de incelenmiştir.

Edebi çeviriye ve çeviri eleştirisine yaklaşırken okuyucunun kişisel değerlendirmeleri de göz önünde bulundurularak çalışılmalıdır. Farklı çeviriler okuyucuların edebi eserlere yaklaşımlarını zenginleştirir düşüncesiyle yola çıkıldığ 1 takdirde, farklı çevirilerin okuyucuların yararına olacağ da ortaya konmuş olur. Bu nedenle, bu çalışmada birbirinden farklı çevirileri incelerken "doğru ve yanlışı" belirlemek esas alınmıştır ve dilimizin zenginliğini göz önüne sererek daha geniş bir çalışma alanı sunulmaya çalışılmıştır. Aksoy'un da (2001, s. 3) belirttiği gibi, çevirmenin görevi, yazınsal kaynak metindeki şiirselliği, yazınsal öğeleri, kendi dilinin ve yazın geleneğinin olanakları elverdiğince tomurcuklandırmaktır, tomurcuklanma sözcüğüyle açıklanmaya çalışılan ise, canlı bir ilişkiyi sağlamaktır.

George Chapman (1559-1634) "Illyada” çevirisinin önsözünde çevirmen tarafindan yapılması gerekenleri sayarken, çevirmenin özgün metnin ruhuna yaklaşmaya çalışmasının gerektiğini ifade eder (Ülsever, 2005, s. 56 içinde Bassnett, 1980, s. 54-58).

Dolet'ye göre iyi bir çevirinin yapılabilmesi için Çevirmen özgün yazarın ne demek istediğini, içlemi ve anlamı, tam olarak anlamalıdır. Bu nedenle Çevirmen anlaşılması güç noktalara açıklık getirmek özgürlüğüne sahiptir, Çevirmen'in kaynak dil ve erek dil üzerinde tam bir hâkimiyeti olmalıdır ve Çevirmen sözcüğü sözcüğüne çeviriden kaçınmalıdır (Öner, 1993, s. 27).

Çeviriyi ister öğrenci yapsın ister profesyonel bir Çevirmen yapsın, Chapman'ın "ruhuna yaklaşma" kıstasına bağlı kalmakta fayda vardır. Çeviri dersinde de bu kıstasa bağlı olarak edebi metinler üzerinde çalış1ırsa, öğrenci bu çizgide çeviri yapmayı öğrenecektir ve bunu benimseyecektir.

Çeviri derslerinde Öner'e göre (1993, s. 47) ayrıca, çeviri eleştirisi konusunun etraflıca ele alınabilmesi için çeviri kuramları ayrıntılı olarak incelenmeli, sorgulanmalı; kuramların temelini oluşturacak varsayımlar üretilmeli ve sınanmalıdır; yalnızca çeviri tarihine değil, aynı zamanda çeviribilim tarihine de her yönüyle ışık tutacak kapsamlı araştırmalar yapılmalıdır; çeviribilim 
felsefesine doğru adımlar atılmalıdır. Böylece ilginin çeviribilimin alt alanlarından üst alanlarına çevrilmesi mümkün olabilir.

$\mathrm{Bu}$ noktada Baykan'ın “çevirinin ister eğitim yoluyla gerçekleştirilmesinde ister kişisel çalışmalarda başarılı olmak için, yani ideal bir çeviriyi gerçekleştirmek için, her iki dilin kültürünü çok iyi tanımak gerektiği”" (Baykan, 2005, s. 185) görüşünü de kabul edebiliriz. Araboğlu'nun (2019, s. 660) görüşüne göre ise, çeviri metnine yeni bir metin olarak, çevirmene ise yeni bir bakış açısı olarak yaklaşılmalıdır. Aksi takdirde çevirmeni ifşa etmenin ve kaynak metinden nelerin eksik olduğunu aramanın ötesine gidilemeyecektir.

Chapman'ın bahsetmiş olduğu eserin "ruhuna inmek" ancak yazarın üslubunu bilmekle mümkün olur. Buna bağlı olarak, edebi eserler sanatçısından bağımsız düşünülemez. Bu yüzden de edebi eser çevirilerinde öncelikle yazarın üslubu korunmalıdır. Ateşman (2001, s. 34), çevirilerde sorunların kültürel özelliklerin çakışmasından dolayı ortaya çıkmadığını savunur. İyi çeviri yapılabilmesi için çeviri yapılacak konuda yazabilecek kadar konunun iyi bilinmesi gerekmektedir. Dili de kültürün bir parçası olarak gördüğümüze göre, her dilsel sorun aynı zamanda bir kültürel sorun olarak sınıflandırılabilir. Doğrudan dilsel olmayan, yani iki dil arasındaki yapısal farklılıktan kaynaklanmayan sorunlar Ateşman'a göre (2001, s. 32) kültürel sorun olarak değerlendirilmelidir. Burada çevirmenin sözcük seçiminde özgür iradesini kullanabileceği vurgulanmaktadır. Çalışmada Çevirmen'in yanı sıra Çeviri eleştirisinin de önemi vurgulanmaya çalışılmıştır. Şöyle ki; çeviri eleştirisinin işlevleri açısından bakıldığı zaman, toplumdaki çeviri uğraşının kalitesinin yükseltilmesine katkıda bulunması, toplumun daha iyi çeviriler istemesini sağlaması ve özellikle de çeviri eğitiminde dil bilincini kuvvetlendirmek, dilsel ve dil dışı ufku genişletmesi gerektiği ortaya konmaktadır (Tosun, 2013, s. 166).

Derste ele alınan, üzerinde tartışılan çevirilerin bu çalışmada kullanılmasının amacı, henüz bu işin başında olan genç kesim ile profesyonel çeviri yapanların aralarındaki farkı ortaya koyabilmektir. Çeviri derslerinde öğrencilere ne kadar çok çeviri yaptırılırsa kendilerini geliştirme fırsatları da o kadar çok olur. Her bir çeviri uygulaması öğrenci için yeni bir deneyim olacağ edecektir. Bunun ders ortamında yapılması ise öğrencinin doğru yönlendirilmesine, farklı bir bakış açısı ile bakabilmesine olanak sağlayacaktır. Öğrencilerden olağanüstü sonuç beklemek doğru olmayacaktır. Ancak çeviri eyleminde çok yetenekli olan öğrencilerimiz de yetişmektedir. Bütün bunlar gösteriyor ki, edebi eser çevirisi ancak uzun yılların vermiş olduğu bilgi ve birikim sonucunda ortaya çıkacak bir çalışmadır. Nihayetinde edebi eser çevirisi yapmak isteyenlerin çeviri yapacakları dilde eser yazacak kadar bilgiye sahip olmaları gerekir ki, dilin kıvraklıklarını, söz oyunlarını ve mecaz anlamları, yerel söylemleri, şiveleri ve dildeki kültürel kodları bilip, bunları kullanarak çeviriler yapabilsin. 


\section{Kaynaklar}

Araboğlu, A. (2019). Çeviri eleştirisinde çevirmenin serüvenini görme(me) biçimimiz. İdil, 57, 653-661.

Aksoy, B. (2001). Çeviride çevirmen seçimleri ışığında çeviri eleştirisi. Hacettepe Üniversitesi Edebiyat Fakültesi Dergisi, 18(2), 1-16.

Ateşman, E. (2001). Kültürel farklardan kaynaklanan çeviri sorunları ve çözüm önerileri. Hacettepe Üniversitesi Edebiyat Fakültesi Dergisi, 18(2), 29-35.

Baykan, A. (2005). Sosyal-kültürel faktörlerin çevirideki rolü. Selçuk Üniversitesi Sosyal Bilimler Enstitüsü Dergisi, (14), 177-197.

Bengi-Öner, I. (1993). Çeviri eleştirisi bağlamında eleş̧irel bilincin oluşması ve eleştiri, üst eleştiri, çeviribilim ilişkileri. Dilbilim Araştırmaları Dergisi, 4, 25-50.

Çoruk, F., Büyük Güler, S. ve Kayalı, Y. (2016). Çeviride kültürel aktarım sorunu: Karamazov kardeşler örneği. Journal of International Social Research, 9(42), 115-121.

Doğan, F. (2012). Tuhaf ylldızlar dünyaya baklyorlar gözlerini kirpmadan: Wedding-Pankow 1976/77. İstanbul: İletişim yayınları.

Güvenç, B. (2003). İnsan ve kültür. İstanbul: Remzi Kitabevi.

Karataş, Z. (2015). Sosyal bilimlerde nitel araştırma yöntemleri. Manevi Temelli Sosyal Hizmet Araştırmaları Dergisi, 1(1), 62-80.

Metzler Lexikon. (2007). Literatur. Begriffe und definitionen. Burdorf, D., Fasbender, C., Moenninghoff, B. (Editör). Stuttgart, Weimar: Verlag Metzler.

Moran, B. (2001). Edebiyat kuramları ve eleştiri. İstanbul: İletişim Yayınları.

Özdamar, E. S. (2003). Seltsame sterne starren zur erde. Köln: Kiepenheuer \& Witsch Verlag.

Stolze, R. (2013). Çeviri kuramları (Çev: Emra Durukan). İstanbul: Değiş̧im Yayınları.

Tosun, M. (2013). Çeviri eleştirisi kuramı. İstanbul: Aylak Adam Kültür Sanat Yayıncılık.

Ülsever, Ş. (2005). Karşılaştırmalı edebiyat ve edebi çeviri. Eskişehir: Metin Ofset Matbaacılık.

Yıldız, Ş. (2004). Çeviride eşdeğerlik ve çeviri kuramları bağlamında karşılaştırmalı bir çalışma. Selçuk Üniversitesi Sosyal Bilimler Enstitüsü Dergisi, 12, 375-386.

Yücel, F. (2007). Çeviri eleştirisi neyi eleştirir? Uludağ Üniversitesi Fen-Edebiyat Fakültesi Sosyal Bilimler Dergisi, 8(12), 39-58. 


\section{Extended Abstract}

The act of translation dates back to the Greek-Roman Antique period. Concretely, translations were first encountered in this period. Its effect was always felt in later periods. Translation and translation criticism are as important as translation. Over time, the need for qualified translation and translators has arisen and translation departments have been constituted in universities. The main intent was to reveal the academic translation perspective, not the market translation one. The study includes sentence translations and paragraph translations belonging to students taking literary translation courses at the university. Translations conducted by students are compared with each other. Students' errors and choices are dealt and it is discussed where the differences may take place. In the conclusion part of the study, the importance of translation and translating is discussed and suggestions to aid students in translation lessons are provided.

While approaching literary translation and criticism, the readers' personal evaluations are also required to be studied. It can be assumed that different translations not only enrich the readers' approach to literary works, they also provide benefits for the readers. Therefore, the purpose of this study is not to determine which one of the translations is right and which is wrong while providing different translations. On the contrary, it is intended to demonstrate the richness of our language on the one hand and on the other hand, to offer a wider field of study on the methods of translation criticism.

The purpose of utilizing student translations in this study is to reveal the difference between young colleagues who are still at the beginning of this job and those who make professional translations. Although, it is not right to expect extraordinary results from students, there have been some students who can be regarded as being very talented in translation. All these aforementioned points indicate that the translation of literary works is a study that will only emerge as a result of knowledge and accumulation of many years. Ultimately, those who want to translate literary works are required to have enough knowledge to write works in the language they will be translating so that they can know the language's agility, phrases and metaphor meanings, local discourses, accents and cultural codes in the target language and make translations using them. If literary texts are studied based on these criteria in the translation course, the students will have already learnt to translate in this direction and adopted it in this way.

In order for translation to be more qualified, the spirit of the text should be descended, a wordfor-word translation should not be sought, and excessively free translation should be avoided. As a result of this study, the same work texts are translated and interpreted by different translators. Hence, translating a work should not be considered as under the monopoly of a single person, instead different translations of different translators should be dealt as the richness of our language. 